Scientia Agricola

http://dx.doi.org/10.1590/1678-992X-2015-0408

\title{
Least limiting water range for oil palm production in Amazon region, Brazil
}

\author{
Michel Keisuke Sato ${ }^{1}$, Herdjania Veras de Lima ${ }^{1 *}$, Raphael Leone da Cruz Ferreira ${ }^{1}$, Sueli Rodrigues ${ }^{2}$, Álvaro Pires da Silva ${ }^{2 \dagger}$
}

\author{
${ }^{1}$ Federal Rural University of Amazon/Institute of Agriculture \\ Science, Av. Perimetral, 2501 - 66077-830 - Belém, PA \\ - Brazil. \\ 2University of São Paulo/ESALQ - Dept. of Soil Science, \\ Av. Pádua Dias, 11, C.P. 09 - 13418-900 - Piracicaba, \\ SP - Brazil. \\ ${ }^{\dagger}$ In memoriam \\ *Corresponding author <herdjania.lima@ufra.edu.br>
}

Edited by: Paulo Cesar Sentelhas

Received October 27, 2015

Accepted May 31, 2016

\begin{abstract}
In areas cultivated with oil palm, typically mechanized field operations using heavy vehicles may negatively affect soil physical properties and productivity. The aim of this study was to evaluate soil physical quality in an area cultivated with oil palm by monitoring the temporal variation of the soil water content and relating it to the critical limits of the least limiting water range. Soil bulk density (Bd), soil penetration resistance (SR), least limiting water range (LLWR), and water stress days (WSD) were used to assess soil physical quality in planting rows (PR) and the traffic zone (TZ) at depths 0-20, 20-40, and 40-60 cm. The Bd was higher and the LLWR was reduced in TZ only at the surface layer. The effect of temporal variation in soil water content on the soil physical quality was higher in TZ, mainly in subsurface layers. Bd and LLWR did not affect the fresh fruit bunch production; however, WSD in TZ at 20-40 and 40-60 cm layers provided evidence of effects of temporal variation of soil water content on oil palm productivity. Keywords: Elaeis guineensis Jacq., soil physical quality, soil compaction, water stress
\end{abstract}

\section{Introduction}

The oil palm Elaeis guineensis Jacq. is a palm tree of African origin that is notable for its high oil production per unit area. In Brazil, its cultivation is concentrated in the northern and northeastern regions and Pará is the main producing state with approximately $90 \%$ of Brazilian production and $85 \%$ of the cultivated area. There is a trend toward increasing the oil palm cultivation area because of its potential for biodiesel production (Ramalho-Filho et al., 2010; Carr, 2011).

In extensive areas cultivated with oil palm, mechanization, usually with heavy vehicles, is used throughout most field operations and machinery traffic often occurs under unfavorable soil moisture conditions. Therefore, the overuse of heavy machinery may negatively affect soil physical properties such as porosity, bulk density, mechanical impedance, and water availability, resulting in soil compaction and loss of soil capacity to provide proper physical conditions for root system development (Zuraidah et al., 2012).

The least limiting water range (LLWR) is defined as the range of soil water content in which there are minimal limitations to plant growth considering water availability, air-filled porosity, and soil mechanical resistance (Silva et al., 1994). The amplitude of LLWR indicates the magnitude at which the soil structure restricts plant growth, that is, in soils with a narrow LLWR, water temporal variations may often predispose crops to physical stress because of poor aeration when the soil is wet or excessive penetration resistance when the soil water content is low (Bengough et al., 2006).

Monitoring temporal variation of the soil water content and evaluating how often this variation occurs within or outside the LLWR are useful tools to make inferences regarding conditions in which plants are more or less subject to physical stress in terms of water availability, aeration, and resistance to root penetration. The
LLWR concept has been used in a range of crops, and this information can help to minimize the impacts of soil structure compaction (Asgarzadeh et al., 2010; Fidalski et al., 2010a; Leão et al., 2006; Tormena et al., 1999). However, to date, no study has evaluated the LLWR in oil palm cultivation. Thus, the objective of our study was to evaluate the soil physical quality in an area cultivated with oil palm by monitoring the temporal variation of the soil water content and relating it to the critical LLWR limits.

\section{Materials and Methods}

This study was conducted in the municipality of Thailand, Pará State, Brazil (2²8'49" S; 4846'37" W; 25 $\mathrm{m}$ above sea level). The total rainfall from Feb 2013 to Jan 2014 (evaluation period) was 2,999 $\mathrm{mm}$, with a total of $11.80 \mathrm{~mm}$ of rain in the driest month (Sept 2013) and $521.80 \mathrm{~mm}$ in the wettest one (Mar 2013) (Figure 1). The soil in this area is classified as Typic Hapludox (Soil Survey Staff, 2010). The soil organic carbon content (Sparks, 1996) and particle-size distribution (Gee and Bauder, 1986) up to $60 \mathrm{~cm}$ depth are presented in Table 1.

The evaluated area covers 34 ha and has been cultivated with oil palm since 1984, with plants spaced at $9 \mathrm{~m}$ $\times 9 \mathrm{~m}$ (143 plants per hectare) in an equilateral triangle design. In 2010, the plantation was renewed using the variety Deli $\times$ Ghana. Seedlings were planted in the same rows between older plants, keeping the same triangular design. Crop residues from previous plants were deposited between planting rows (stacking zone) to decompose and be gradually incorporated into the organic material of the soil. Thus, spaces adjacent to planting rows (inter-row) were intercalated between the stacking and traffic zones.

Main field operations involving vehicular traffic are fertilization (Nov and Mar), weed control (three times a year), and bunch harvest (twice a month). For all these operations, a $2318 \mathrm{~kg}$-tractor coupled to a metallic trailer (weighing $830 \mathrm{~kg}$ ) with a cargo capacity of 4000 


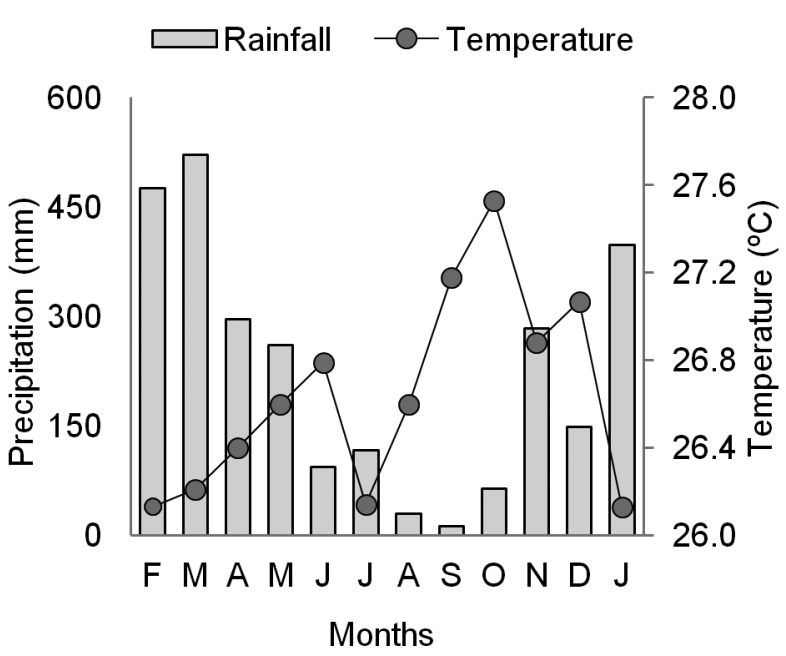

Figure 1 - Mean monthly precipitation and temperature during between Feb 2013 and Jan 2014.

Table 1 - Results of particle size analysis (clay, silt and sand) and organic carbon content in three soil layers.

\begin{tabular}{lccccc}
\hline Layer $(\mathrm{cm})$ & Textural class & $\begin{array}{c}\text { Clay } \\
(<2 \mu \mathrm{m})\end{array}$ & $\begin{array}{c}\text { Silt } \\
(2-50 \mu \mathrm{m})\end{array}$ & $\begin{array}{c}\text { Sand } \\
(50-200 \mu \mathrm{m})\end{array}$ & OC \\
\cline { 3 - 6 } & & $\mathrm{g} \mathrm{kg}^{-1}$ & & \\
\cline { 3 - 6 } $0-20$ & Sand clay loam & 243.0 & 69.2 & 687.9 & 7.33 \\
$20-40$ & Sand clay & 366.9 & 61.9 & 571.2 & 5.57 \\
$40-60$ & Sand clay & 412.5 & 50.4 & 537.1 & 2.26 \\
\hline
\end{tabular}

$\mathrm{OC}=$ Organic carbon.

kg or a pulverizing tank (weighing $1000 \mathrm{~kg}$ ) and capable of holding $2000 \mathrm{~L}$ was used.

The legume Pueraria phaseoloides was kept in interrows to fix nitrogen in the soil, prevent weed growth, keep the soil covered, and incorporate organic matter.

For this study, 30 plants were selected from six uniformly distributed lines and the weight of the fresh fruit bunch (FFB) was measured every month during Feb 2013 - Jan 2014. During the same period, the soil water content was monitored at depths 0-20, 20-40, and $40-60 \mathrm{~cm}$ at points $2.4 \mathrm{~m}$ away from selected plants, as recommended by Peralta et al. (1985), in two positions: planting row (PR) and traffic zone (TZ). The gravimetric soil water content was measured according to Gardner (1986) and the monitoring depth was defined based on the effective depth of the root distribution of the oil palm crop, which was $60 \mathrm{~cm}$ (Carr, 2011).

Adjacent to points where the soil water content was monitored, the undisturbed soil samples were collected from the intermediate section 0-20, 20-40, and 40$60 \mathrm{~cm}$ layers using soil cores with $5 \mathrm{~cm}$ diameter and height to determine soil bulk density (Bd) (Blake and Hartge, 1986), soil penetration resistance curve (SRC), and soil water retention curve (SWRC).

A total of 180 undisturbed samples (30 points $\times$ 3 layers $\times 2$ positions) were collected. In the laboratory, these samples were saturated by gradually raising the water level over $48 \mathrm{~h}$, weighed and the samples were grouped into six groups of ten. Then, one sample from each group was subjected to one of the following matric potentials: $-0.003,-0.006,-0.01,-0.03,-0.06,-0.1,-0.3,-0.6,-1$, and -1.5 MPa in a Richard's pressure plate (Klute, 1986). When water equilibrium was reached at each potential, the samples were weighed, and their soil penetration resistance (SR) was determined using a static electronic penetrometer with rod displacement at a constant speed of $10 \mathrm{~mm} \mathrm{~min}^{-1}$, supplied with a conical tip and penetration angle $60^{\circ}$. After determining SR, the samples were oven dried at $105{ }^{\circ} \mathrm{C}$ until they reached a constant mass to determine the water content $(\theta)$ and $\mathrm{Bd}$ (Blake and Hartge, 1986).

To fit the SRC, the non-linear model proposed by Busscher (1990) was used following the procedures described by Silva et al. (1994):

$\mathrm{SR}=a \theta^{b} \mathrm{Bd}^{\mathrm{c}}$

where: SR is the soil penetration resistance $(\mathrm{MPa}) ; \theta$ is the volumetric water content $\left(\mathrm{m}^{3} \mathrm{~m}^{-3}\right)$; $\mathrm{Bd}$ is the soil bulk density $\left(\mathrm{Mg} \mathrm{m}^{-3}\right)$; and $a, b$, and $c$ are the model fitting parameters.

The SWRC was fitted to the equation adapted from Williams et al. (1993), which incorporates the effect of $\mathrm{Bd}$ into the model that expresses $\theta$ as a function of the matric potential $(\Psi)$ :

$\theta=\exp (d+e \mathrm{Bd}) \Psi^{f}$

where: $|\Psi|$ is the matric potential (MPa) in absolute value and $d, e$, and $f$ are the model fitting parameters.

To obtain the parameters used to determine LLWR, a non-linear regression based on SWRC and SRC was performed using the statistical software SAS (Statistical Analysis Software, version 9.0), as described by Leão et al. (2005).

After estimating all of the model parameters $(a$, $b, c, d, e, f)$, the soil moisture values at field capacity or $\Psi=-0.01 \mathrm{MPa}(\theta \mathrm{FC})$, at wilting point or $\Psi=-1.5 \mathrm{MPa}$ ( $\theta \mathrm{WP})$ (Cassel and Nielsen, 1986), at air-filled porosity 10 $\%$ (ӨAFP) (Grable and Siemer, 1968), for which the soil penetration resistance reached the critical value of 2.5 MPa (ӨSR) (Sene et al., 1985), were obtained.

Although the SR value of $2 \mathrm{MPa}$ is considered critical in most studies, values ranging from 1.5 to $3.5 \mathrm{MPa}$ are suggested as critical for some crops (Bengough and Mullins, 1990; Oliveira et al., 2016). Furthermore, according to Ehlers et al. (1983), root growth is normal at SR $\geq 3.5$ in the field, since, in this condition, pores sizes are more heterogeneous, especially related to biopores. Thus, since there is no information about SR critical limits for root growth of oil palm and considering the characteristics of the area (perennial crop and legume planting in the interrows), an intermediate value between the limits suggested in the literature (1.5 to $3.5 \mathrm{MPa}$ ) was adopted. 
For each $\mathrm{Bd}$, we calculated LLWR as the difference between the upper and lower limits, where the upper limit is the drier $\theta$ of either $\theta \mathrm{FC}$ or $\theta \mathrm{AFP}$, and the lower limit is the wetter $\theta$ of either $\theta \mathrm{WP}$ or $\theta \mathrm{SR}$ /Silva et al., 1994).

The effect of a water deficit was evaluated, caused by temporal variation of the soil water content, on oil palm productivity, using the term water stress day (WSD) proposed by Benjamin et al. (2003) to characterize in-season water dynamics and relate the effects of soil condition to plant growth. WSD was determined by a simple calculation that accounts for water stress (soil water content below the lower LLWR limit) during the period evaluated. Cumulative WSD was calculated by:

$\mathrm{WSD}=\Sigma(\theta \mathrm{d}-\theta \mathrm{LL}) \times 100$

where: $\theta \mathrm{d}$ is the soil water content ascertained during monitoring and $\theta \mathrm{LL}$ is the lower limit of LLWR for the condition $\theta \mathrm{d}<\theta \mathrm{LL}$; otherwise, WSD is considered zero.

The uniformity or heterogeneity of the data was analyzed using the descriptive statistics and the means of the sampling positions (PR and TZ) were compared by the Tukey's test at a $5 \%$ significance level. The data on $\mathrm{Bd}, \mathrm{SR}, \theta$, and $\Psi$ were fitted using nonlinear regression models for the three layers and incorporated the variable sampling position.

To describe the effect of changes in the soil physical properties and the temporal water variation on oil palm production, we performed a multiple regression analysis on the soil physical quality indicators $(\mathrm{Bd}, \mathrm{LLWR}$, and WSD) for each layer and sampling position (independent variables) and FFB production (dependent variable). The significance level of the parameters $(p \leq 0.15)$ was used to select variables from the model, according to Silva et al. (1994).

\section{Results}

The descriptive analysis (Table 2) showed a wide variation in the $\mathrm{Bd}, \mathrm{SR}$, and $\theta$ values in the two positions and three layers, which is desirable for fitting SWRC and SRC. SR is highlighted by the high coefficient of variation.

The sampling position revealed differences in $\mathrm{Bd}$ only in the 0-20 cm layer (Table 2), in which $\mathrm{Bd}$ was higher in TZ. In the other layers, there was no difference in $\mathrm{Bd}$ with respect to the sampled position. In addition to the higher $\mathrm{Bd}$ value, the $\mathrm{TZ}$ position in the $0-20 \mathrm{~cm}$ layer also had the lowest $\theta$ and highest SR values. In the other layers $(20-60 \mathrm{~cm})$, there were no changes in these two soil attributes regarding the sampling position.

Table 3 shows the fitted equations of SWRC and SRC for the three layers. The nonlinear models used to fit SRC (Busscher, 1990) and SWRC (Williams et al., 1993) were appropriate for the data distribution $(p \leq 0.0001)$. The model used for SRC explained $>97 \%$ of the variability in the penetration resistance data while the mod-
Table 2 - Descriptive analysis of some soil physical properties for the three layers, using undisturbed samples.

\begin{tabular}{|c|c|c|c|c|c|c|}
\hline Layer (cm) & $\begin{array}{c}\text { Planting } \\
\text { row }\end{array}$ & $\begin{array}{l}\text { Traffic } \\
\text { zone }\end{array}$ & Mean & Min. & Max. & CV (\%) \\
\hline \multicolumn{7}{|c|}{ Bulk density $\left(\mathrm{Mg} \mathrm{m}^{-3}\right)$} \\
\hline $0-20$ & $1.60 \mathrm{~b}$ & $1.68 \mathrm{a}$ & 1.64 & 1.45 & 1.77 & 5 \\
\hline $20-40$ & $1.53 \mathrm{a}$ & $1.55 \mathrm{a}$ & 1.54 & 1.33 & 1.68 & 5 \\
\hline $40-60$ & $1.50 \mathrm{a}$ & $1.50 \mathrm{a}$ & 1.50 & 1.35 & 1.78 & 6 \\
\hline \multicolumn{7}{|c|}{ Soil water content $\left(\mathrm{m}^{3} \mathrm{~m}^{-3}\right)$} \\
\hline $0-20$ & $0.222 \mathrm{a}$ & $0.190 \mathrm{~b}$ & 0.206 & 0.199 & 0.345 & 30 \\
\hline $20-40$ & $0.239 a$ & $0.234 a$ & 0.237 & 0.141 & 0.348 & 25 \\
\hline $40-60$ & $0.250 a$ & $0.245 a$ & 0.248 & 0.134 & 0.431 & 21 \\
\hline \multicolumn{7}{|c|}{ Soil penetration resistance $(\mathrm{MPa})$} \\
\hline $0-20$ & $2.22 b$ & $3.90 \mathrm{a}$ & 3.06 & 0.78 & 12.48 & 79 \\
\hline $20-40$ & $3.59 \mathrm{a}$ & $4.14 \mathrm{a}$ & 3.87 & 0.54 & 12.28 & 91 \\
\hline $40-60$ & $3.48 \mathrm{a}$ & $3.67 \mathrm{a}$ & 3.58 & 0.57 & 10.83 & 91 \\
\hline
\end{tabular}

$\mathrm{CV} \%$ = coefficient of variation; Min. = minimum value; Max. = maximum value; Means followed by the same letters, in each row, did not differ by the Tukey test $(p \leq 0.05)$.

Table 3 - Fitted models for soil penetration resistance curve and soil water retention curve for the three layers.

\begin{tabular}{|c|c|c|c|}
\hline $\begin{array}{l}\text { Layer } \\
\text { (cm) }\end{array}$ & Equation & $\mathrm{R}^{2}$ & $\mathrm{~F}$ \\
\hline \multicolumn{4}{|c|}{ Soil penetration resistance curve $\left(S R=a \theta^{b} B d^{c}\right)$} \\
\hline $0-20$ & $\mathrm{SR}=0.0131 \theta^{-2.053} \mathrm{Bd}^{3.848}$ & 0.98 & $656.78^{* *}$ \\
\hline $20-40$ & $\mathrm{SR}=0.0036 \theta^{-3.113} \mathrm{Bd}^{4.703}$ & 0.97 & $482.16^{* *}$ \\
\hline $40-60$ & $\mathrm{SR}=0.0005 \theta^{-4.577} \mathrm{Bd}^{5.167}$ & 0.99 & $831.28^{* *}$ \\
\hline \multicolumn{4}{|c|}{ Soil water retention curve $\left(\theta=\exp (d+e B d) \Psi^{f}\right)$} \\
\hline $0-20$ & $\theta=\exp (-0.6016+(-0.8081 \mathrm{Bd})) \Psi-0.125$ & 0.99 & $1592.06^{* *}$ \\
\hline $20-40$ & $\theta=\exp (-1.0883+(-0.4154 \mathrm{Bd})) \Psi^{-0.109}$ & 0.99 & $7581.95^{* *}$ \\
\hline $40-60$ & $\theta=\exp (-1.1830+(-0.2964 \mathrm{Bd})) \Psi^{-0.081}$ & 0.99 & 2794.19 ** \\
\hline
\end{tabular}

el used for SWRC explained $99 \%$ of the variation in the soil water content (Table 3).

The parameters estimated for the SRC model confirm that $\mathrm{SR}$ is negatively related to $\theta$ and positively related to Bd. For SWRC, $\theta$ varied negatively with both Bd and $\Psi$.

Figures 2A, $\mathrm{C}$ and $\mathrm{E}$ show the variation of $\theta$ as a function of $\mathrm{Bd}$ considering the limiting factors related to the water potential, aeration, and penetration resistance in the three layers. Increasing $\mathrm{Bd}$ had a negative effect on the soil capacity to retain water. The available water $(\theta \mathrm{FC}-$ $\theta \mathrm{WP}$ ) presented a slight negative correlation with increasing Bd. Air-filled porosity ( $\theta \mathrm{AFP})$ was not a limiting factor for the soil in any layer of the site studied. This result can be observed by the higher $\theta$ values at the minimum airfilled porosity $(\theta \mathrm{AFP})$ in relation to $\theta \mathrm{FC}$ (Silva et al., 1994).

In the $0-20 \mathrm{~cm}$ layer, $\theta \mathrm{FC}$ and $\theta \mathrm{WP}$ represented the LLWR upper and lower limits, respectively, for $\mathrm{Bd}$ values below $1.47 \mathrm{Mg} \mathrm{m}^{-3}$. From this point onward, the lower limit became the water content at which the soil reached the critical penetration resistance $2.5 \mathrm{MPa}(\theta \mathrm{SR})$, indicating possible soil physical constraints within the 
available water range. For all other layers, $\theta S R$ was the lower limit for the entire $\mathrm{Bd}$ range. Increasing $\mathrm{Bd}$ led to a LLWR reduction until it became null, where the curves intersect. At this point, it was determined the critical soil bulk density (Bdc) for the three layers, which were 1.77 , 1.68 , and $1.65 \mathrm{Mg} \mathrm{m}^{-3}$ for the $0-20,20-40$ and $40-60 \mathrm{~cm}$ layers, respectively (Figures $2 \mathrm{~B}, \mathrm{D}$, and $\mathrm{F}$ ).

Taking into account the $\mathrm{Bd}$ means for $\mathrm{PR}$ and $\mathrm{TZ}$ sampling positions (Table 2) in the 0-20 cm layer, LLWR was lower in TZ compared to PR (Figure 2B). In the sub- surface layers $(20-40$ and $40-60 \mathrm{~cm})$, there were no differences in the LLWR with respect to the sampling position (Figures 2D and $\mathrm{F}$ ).

Figures $3 \mathrm{~A}, \mathrm{~B}, \mathrm{C}, \mathrm{D}, \mathrm{E}$ and $\mathrm{F}$ illustrate the monthly variation in $\theta$ during a year, in relation to LLWR, for two positions and three depths. Considering LLWR calculated from the mean values of $\mathrm{Bd}$ for each position and layer (Table 2), it was noted a wide variation in $\theta$ during the evaluated period, with a maximum $0.33 \mathrm{~m}^{3} \mathrm{~m}^{-3}$ and a minimum $0.13 \mathrm{~m}^{3} \mathrm{~m}^{-3}$.
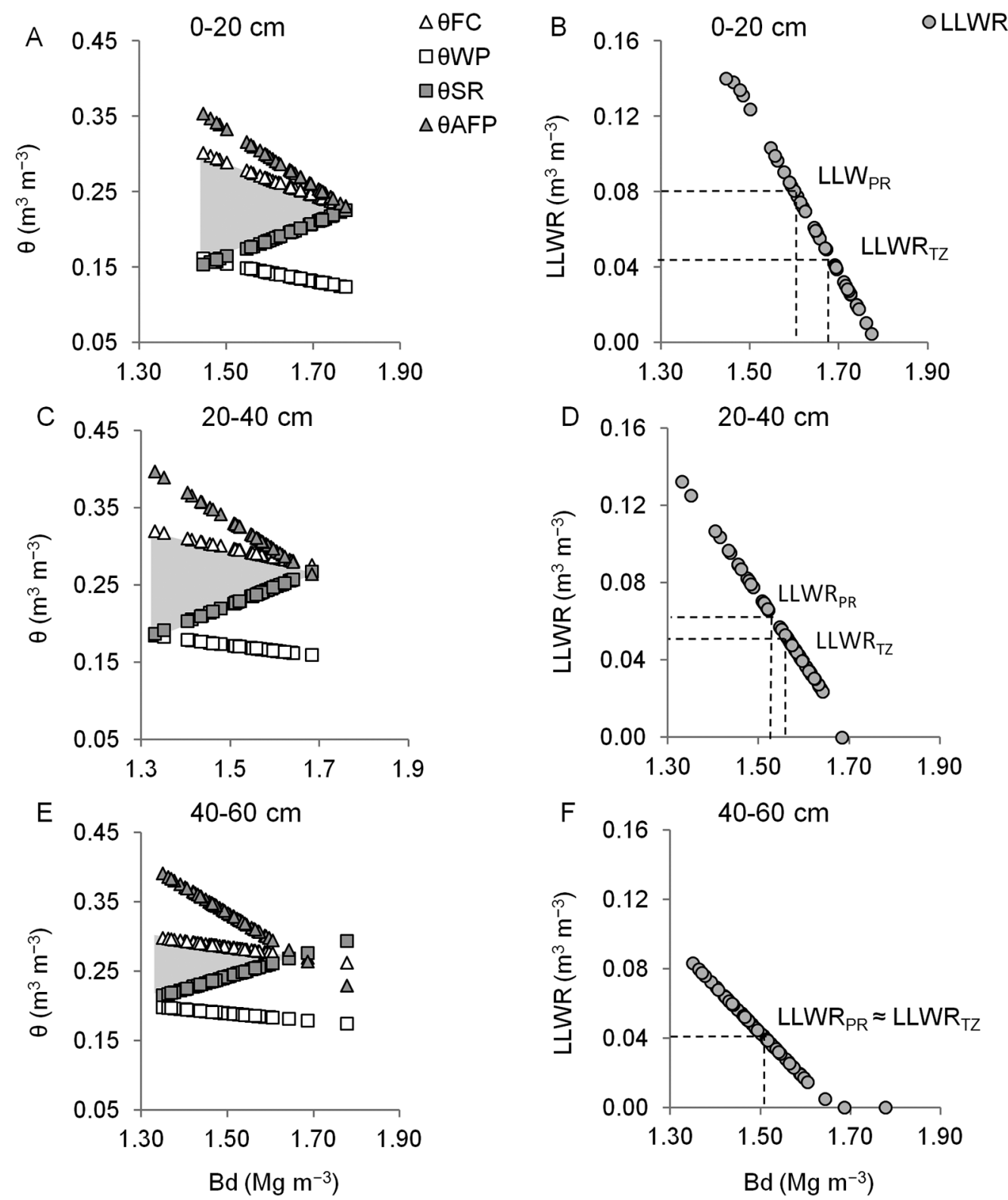

Figure 2 - On the left, the soil water content $(\theta)$ variation as a function of soil bulk density $(\mathrm{Bd})$ at field capacity $(\theta \mathrm{FC})$ and permanent wilting point $(\theta W P)$ and critical levels of aeration porosity ( $\theta$ AFP) and penetration resistance $(\theta S R)$ at 0-20 (A), $20-40$ (C) and $40-60 \mathrm{~cm}(\mathrm{E})$. On the right, the

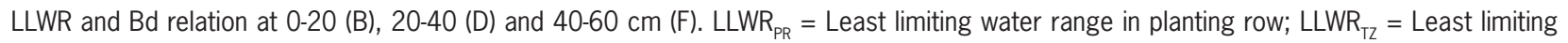
water range in traffic zone. 
In the PR position in the $0-20 \mathrm{~cm}$ layer, the water content was out of LLWR only in a few occasions, particularly during Aug to Oct (Figure 3A). Except for this position in this layer, $\theta$ during the monitoring period was often outside LLWR, especially for the lower limit. However, we also noted some means of $\theta$ above the upper limit. While in the monitoring period, the $\theta$ value exceeded the upper limit especially in the months of Feb and Mar (Figure 3C), the excess water was not a limit- ing factor in the area because the soil (Typic Hapludox) is deep and well drained and the high value of $\theta$ was attributed to the high precipitation levels prior to soil sampling. This condition did not persist for very long since the water quickly drained. Therefore, the oil palm plants underwent stress due to the low water content and high SR.

The period from Aug to Dec showed the soil water content more often below the lower LLWR limit. Us-

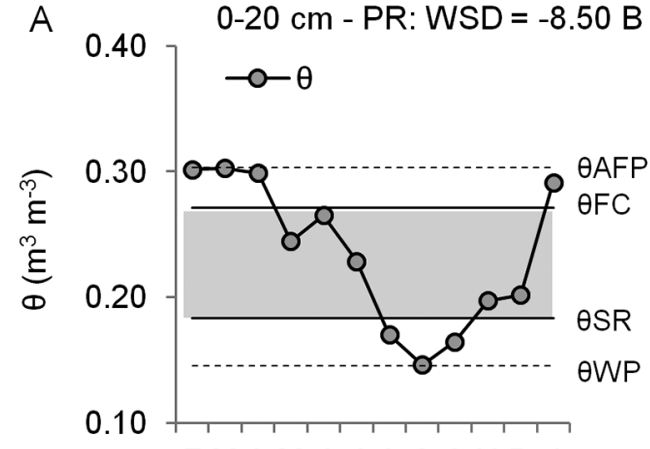

FMAM J JASOND J
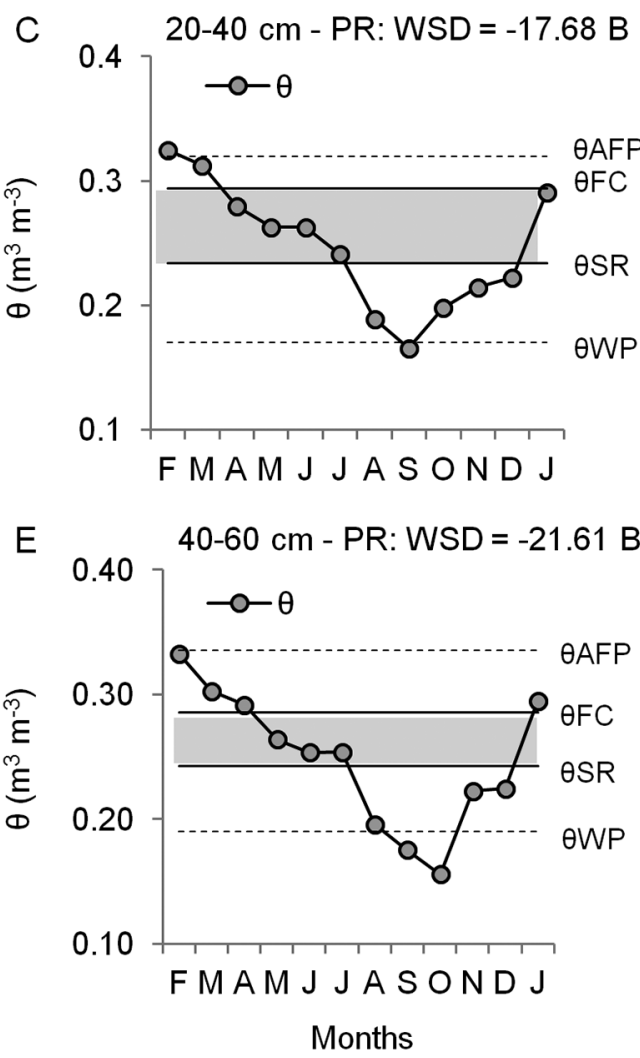
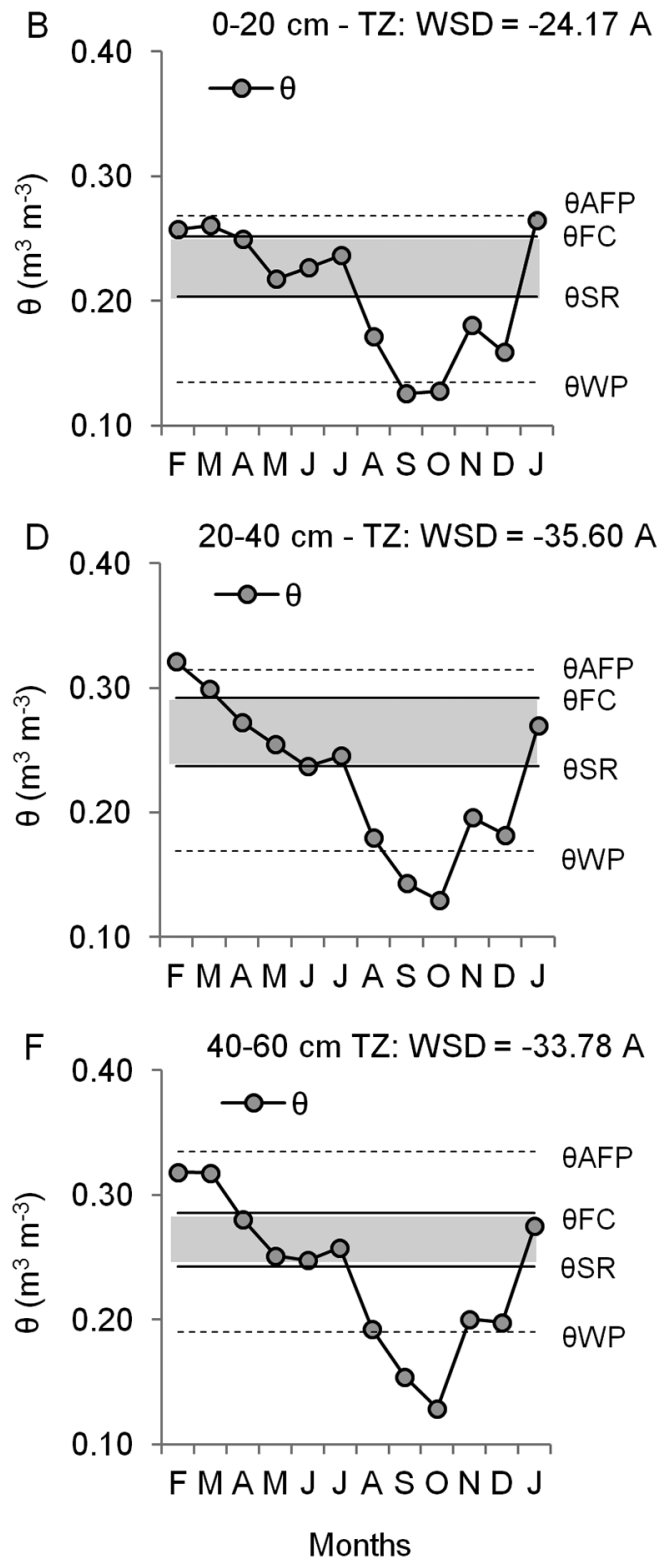

Figure 3 - Temporal variation of soil water content $(\theta)$ in the planting row (PR) at 0-20 (A), 20-40 (C), and 40-60 cm (E) and traffic zone (TZ) at 0-20 (B), 20-40 (D) and 40-60 cm (F). $\theta F C$ = Soil water content at field capacity; $\theta W P$ = Soil water content at permanent wilting point; $\theta$ AFP $=$ Soil water content at critical levels of aeration porosity; $\theta S R=$ Soil water content at critical levels of penetration resistance. The filled area represents the least limiting water range (LLWR). Means of water stress days (WSD) followed by the same letters, between sampling position, for each layer, did not differ by the Tukey test $(p \leq 0.05)$. 
ing the fitted equation determined for SRC (Table 3), the mean values of $\mathrm{Bd}$ (Table 2) and $\theta$ in Sept (driest month) (Figures 1 and $3 \mathrm{~A}, \mathrm{~B}, \mathrm{C}, \mathrm{D}, \mathrm{E}$ and F), SR for the three layers in $\mathrm{PR}$ and $\mathrm{TZ}$ positions were calculated. The SR values were 3.9, 6.6, and 9.9 $\mathrm{MPa}$ for the 0-0, 20-40, and 40-60 cm layers, respectively, in the PR position and $6.4,12.8$, and $22.8 \mathrm{MPa}$ for the $\mathrm{TZ}$ position, respectively. Moreover, the $\theta$ value in this month was below the permanent $\theta \mathrm{WP}$.

The water stress period experienced by the plants, due to temporal variation in the soil water content, was quantified through the WSD values. The greatest stress occurred in the $\mathrm{TZ}$ position, regardless of the measured layer ( $p \leq 0.05$; Figures $3 \mathrm{~A}, \mathrm{~B}, \mathrm{C}, \mathrm{D}, \mathrm{E}$ and F). WSD was higher in the 20-40 and 40-60 cm layers.

The FFB production during the studied period varied widely (Figure 4) with a minimum $0.20 \mathrm{t} \mathrm{ha}^{-1}$ (July) and a maximum $2.93 \mathrm{t} \mathrm{ha}^{-1}$ (Sept). The analysis of variance (ANOVA) was not significant $(p>0.05)$ and the low coefficient of determination $\left(R^{2}\right)$ values from the multiple regression relating $\mathrm{Bd}$ and LLWR with FFB revealed that these indicators did not affect the oil palm production during the evaluation period. However, the WSD variation contributed to the FFB fluctuation $(p \leq$ 0.05 ) and was responsible for $>73 \%$ of variability in FFB production (Table 4).

Analyzing the parameters obtained from the multiple regressions between WSD and FFB for the three layers and two sampling positions, we observed that only the WSD variability in the 20-40 and 40-60 cm layers in the TZ position, were significant to estimate FFB ( $p \leq$ 0.15) (Table 4). These results showed that this sampling position (TZ) is better to predict the oil palm production from the WSD variability. Thus, the multiple regression equation is given by:

$\mathrm{FFB}=\mathrm{c}_{0}+\mathrm{c}_{5} \mathrm{WSD}_{20-40 \mathrm{TZ}}+\mathrm{c}_{6} \mathrm{WSD}_{40-60 \mathrm{TZ}}$

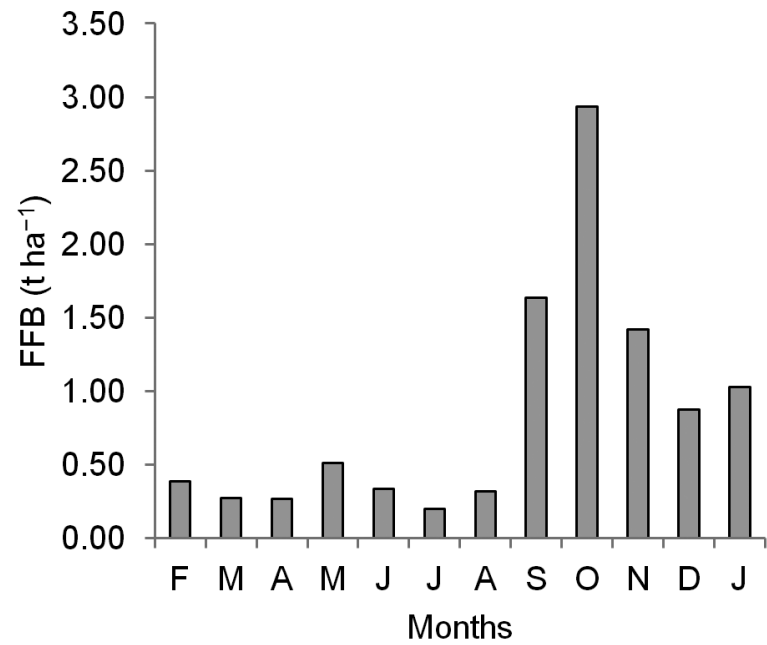

Figure 4 - Variability of the fresh fruit bunch (FFB) production during the assessment period (Feb 2013 to Jan 2014).
Table 4 - Multiple regression and coefficient analysis for the relationship of fresh fruit bunches (FFB) production with water stress day (WSD), in three layers and two sampling sites: * $\mathrm{FFB}=$ $\mathrm{C}_{0}+\mathrm{C}_{1} \mathrm{WSD}_{0.20 \mathrm{PR}}+\mathrm{C}_{2} \mathrm{WSD}_{20-40 \mathrm{PR}}+\mathrm{C}_{3} \mathrm{WSD}_{40-60 \mathrm{PR}}+\mathrm{C}_{4} \mathrm{WSD}_{0.20 \mathrm{TZ}}+\mathrm{C}_{5}$ $\mathrm{WSD}_{20-40 \mathrm{TZ}}+\mathrm{C}_{6} \mathrm{WSD}_{40-60 \mathrm{TZ}}$

\begin{tabular}{lccrr}
\hline Coefficient & Estimated value & Standard error & \multicolumn{1}{c}{$\mathrm{t}$} & \multicolumn{1}{c}{$\mathrm{p}>\mathrm{t}$} \\
\hline $\mathrm{C}_{0}$ & 57.643 & 5.397 & 10.680 & $<0.001$ \\
$\mathrm{C}_{1}$ & 0.044 & 0.307 & 0.144 & 0.888 \\
$\mathrm{C}_{2}$ & -0.335 & 0.234 & -1.429 & 0.177 \\
$\mathrm{C}_{3}$ & 0.010 & 0.304 & 0.033 & 0.974 \\
$\mathrm{C}_{4}$ & -0.076 & 0.169 & -0.453 & 0.658 \\
$\mathrm{C}_{5}$ & 0.418 & 0.166 & 2.513 & 0.026 \\
$\mathrm{C}_{6}$ & 0.349 & 0.153 & 2.277 & 0.040 \\
\hline $\mathrm{PR}=$ Planting row; TZ $=$ Traffic zone; ${ }^{*}$ Multiple regression analysis: $\mathrm{F}=5.96 ;$
\end{tabular}
$p<0.05 ; R^{2}=0.73$

where: FFB is the fresh fruit bunch $\left(\mathrm{t} \mathrm{ha}^{-1}\right)$; $\mathrm{WSD}_{20-40 \mathrm{TZ}}$ and $\mathrm{WSD}_{40-60 \mathrm{TZ}}$ are the water stress periods in the traffic zone in the 20-40 and 40-60 cm layers, respectively; and $\mathrm{c}_{0}, \mathrm{c}_{5}$, and $\mathrm{c}_{6}$ are the equation fit parameters.

\section{Discussion}

Since SWRC and SRC were determined for a range of matric potentials, the high SR variability $(\mathrm{CV}>79 \%)$ was due to the wide variation in the soil water content. These results are consistent with those of other studies (Silva et al., 1994; Fidalski et al., 2010b) and highlight the fundamental role of $\theta$ to prevent the soil from reaching limiting the SR values for plant growth.

The differences between $\mathrm{Bd}$ and SR for the PR and $\mathrm{TZ}$ positions in the surface layer $(0-20 \mathrm{~cm})$ are related to field crop management. Soil tillage with plowing and harrowing is performed only once during crop implantation, and from then onward, the soil is no longer tilled throughout the entire production cycle. Therefore, the effect of soil compaction on the traffic zone due to the passage of machinery accumulates over the years.

The observed relationship between SR, $\theta, \mathrm{Bd}, \theta$, and $\Psi$ from the model parameters (Table 3) are consistent with those reported in several studies relating these variables (Silva et al., 1994; Leão et al., 2005). Typically, an increase in $\mathrm{Bd}$ is followed by a concomitant increase in the volume of micropores and a reduction in the macropores, as reported in many studies (Leão et al., 2006; Olibone et al., 2010; Wilson et al., 2013). However, a different relation has also been reported (Fidalski et al., 2010a; Safadoust et al., 2014; Cecagno et al., 2016) and was the result of a reduction in the volume of pores, both because of macroporosity and microporosity. With increasing $\mathrm{Bd}$, the volume of micropores was slightly reduced, resulting in the decrease of $\theta \mathrm{FC}$.

Considering the $\theta$ value within the available water $(\theta \mathrm{AFP}-\theta \mathrm{WP})$, there was no limitation due to aeration porosity (Figures $2 \mathrm{~A}, \mathrm{C}$ and $\mathrm{E}$ ). These results agree with those shown by Silva et al. (1994) who considered this a common behavior for soils of similar texture. The 
higher number of macropores in coarser soils, resulting from the arrangement of larger particles with regard to smaller ones, allows Bd to vary widely without impairing soil aeration.

When the upper and lower limits of LLWR coincide with the available water, the soil physical restrictions on plant growth are minimal. This condition was observed in less than $1 \%$ of samples from the surface layer, indicating that even with available water, there is a great potential, especially in relation to $\mathrm{SR}$, for obstacles to root growth in the oil palm, primarily in subsurface layers where the LLWR lower limit was $\theta$ SR in the entire $\mathrm{Bd}$ range, that is, all samples showed potential for SR to limit root growth.

Many studies have suggested SR as the main physical attribute that reduces LLWR in tropical soils (Silva et al., 1994; Beutler et al., 2007; Fidalski et al., 2010a; Wilson et al., 2013). This is because SR is highly susceptible to the soil physical variations such as $\mathrm{Bd}, \theta$, clay content, and soil organic carbon (Safadoust et al., 2014).

The finding that all $\mathrm{Bd}$ means were above $90 \%$ of Bdc confirms the strong potential for the soil physical properties to restrict root development in oil palm. This is because the closer the Bdc, the lower the LLWR (Figures 2B, D and F), therefore, the $0-20 \mathrm{~cm}$ layer, in the $\mathrm{TZ}$ position, presents a higher probability that temporal variation in the $\theta$ value will restrict root growth, due to the high SR (Silva and Kay, 1997).

Studies on soil oxygen diffusion indicate that when the values of aeration porosity fall below $0.10 \mathrm{~m}^{3} \mathrm{~m}^{-3}$, the oxygen diffusion rate and gas exchange in the soil become insufficient to supply root demand, hindering plant growth (Grable and Siemer, 1968; Beutler et al., 2007). This restriction may occur due to high $\theta$ and/or high $\mathrm{Bd}$. Little is known about the oil palm response to reduced soil aeration caused by water excess. However, its origins in regions that experience periodic flooding indicate that oil palm can withstand low levels of soil aeration without compromising the growth provided that the flooding is not permanent (Carr, 2011). Considering the wettest months, even in Feb when aeration porosity reached a critical level in the $20-40 \mathrm{~cm}$ layer, conditions above the field capacity and below $10 \%$ aeration porosity in the other layers (Figures 3A, B, C, D, E and F) may have enabled efficient gas exchange in the root system of oil palm.

Similar results, shown in Figures 2A, C and E, was reported by Beutler et al. (2007) in a study conducted with soybean crops (Glycine max L.) in tropical soils. According to these authors, as long as there is a minimum of $10 \%$ aeration, root growth is not limited. Therefore, using the field capacity to indicate soil physical limitation during temporal variations in $\theta$ seems to be rather irrelevant, as long as the $\theta$ value is above this limit, if it does not exceed the minimum aeration porosity $(10 \%)$, plant growth is not affected.

Despite its high demand for water, oil palm has a great ability to survive even in dry periods due to its ef- ficient stomatal system and its ability to reduce leaf area when availability of soil water is low. These mechanisms restrain photosynthesis and the mobility of photoassimilates to reproductive sites, resulting in fluctuations in crop yield (Ramalho-Filho et al., 2010).

Since $\theta$ controls various soil physical properties that directly affect plant physiological processes (Letey, 1985), the reduction in $\theta$ may have restricted oil palm development, due to the high SR, above $2.5 \mathrm{MPa}$ from Aug to Dec. This restriction was enhanced in Sept and Oct due to soil water deficit $(\theta<\theta \mathrm{WP})$ (Figures 3A, B, C, D, E and F).

The soil physical condition was altered in the surface layer in $\mathrm{TZ}$ (higher $\mathrm{Bd}$ and lower LLWR) compared to the PR position. This situation may have reduced the capacity for water infiltration to subsurface layers, resulting in a decrease in water storage in the soil, and consequently, increasing the period of hydrophysical stress during the evaluation period.

We found no relationship between Bd and LLWR and FFB. This result indicates that other factors contributed to variability in the FFB production. Another reason may be related to the critical limits used. Since there are no studies that evaluate the LLWR limits for oil palm production, we used well-known limits for these plant species to check their suitability. However, further research is needed to determine the specific critical values for oil palm. Benjamin et al. (2003) stated that indicators of soil quality such as Bd and LLWR are static and, thus, may not be suitable to assess crop response when there are limitations due to water availability in the soil. In this case, it is adequate to include temporal variation in $\theta$ during the assessment period.

Corroborating the findings of Benjamin et al. (2003), the greater $\mathrm{R}^{2}$ obtained from multiple regression between FFB and WSD indicated the higher sensitivity of WSD as an indicator of soil physical quality when the temporal variation in $\theta$ limits plant growth. Benjamin et al. (2003) believed that this indicator obtained from LLWR could reveal and quantify the period when the plant was subjected to soil physical conditions that restricted its growth and could facilitate the monitoring of soil quality in order to adopt soil management practices that allow to achieve sustainable crop production.

The multiple regression analyses for FFB in relation to WSD suggest that oil palm productivity is more sensitive to changes in the soil physical properties that occur in subsurface layers, especially in TZ. This result was probably due to differences in sensitivity and absorption rates of water and nutrients by the root system of oil palm.

According to Zwieniecki et al. (2002), root zones next to the apex have a greater capacity for water absorption due to the lower content of hydrophobic material in the root tissue. However, these zones are highly sensitive to changes in the environment due to their lower rate of tissue differentiation. Thus, low $\theta$ in subsurface layers, below the lower LLWR limit, from Aug to 
Dec (Figures 3A, B, C, D, E and F), may have diminished water and nutrient absorption by oil palm, resulting in reduced FFB production.

These results indicate that soil compaction in the surface layer in $\mathrm{TZ}$ has an indirect influence on $\mathrm{FFB}$ production, which may have been caused by a reduction in water infiltration and redistribution at greater depths, which was reflected by reduced water storage in the subsurface layers. In this situation, there is an increase in the cohesive forces between water molecules that are strongly adhered to the particle surfaces, causing increased agglutination and friction between the soil particles. Therefore, SR may reach critical levels even in conditions of non-restrictive bulk density (Lal and Shukla, 2005).

Despite the evidence of our data, more research is necessary in oil palm cultivated areas in different climatic conditions and soils, in order to improve our knowledge about the combined effects of machine traffic and temporal variation of $\theta$ on oil palm production. The results presented in this study support the need to monitor soil physical quality to ensure high and uniform oil palm productivity throughout the year.

\section{Conclusions}

Traffic zone areas presented changes in soil physical quality only in the surface layer, resulting in a higher soil bulk density and reduced least limiting water range.

The effect of temporal variation of the soil water content on soil physical quality was higher in the traffic zone, mainly in the subsurface layers due the longer period for which the soil physical and water conditions were restricted.

The soil bulk density and least limiting water range did not affect the fresh fruit bunch production; however, the water stress day in the traffic zone in the 20-40 and 40-60 cm layers were better indicators of the effect of temporal variation in the soil water content on oil palm productivity.

\section{Acknowledgments}

To Brazilian National Council for Scientific and Technological Development (CNPq) for providing a Master's scholarship to the first author and Agropalma for the support and encouragement for this research.

\section{References}

Asgarzadeh, H.; Mosaddeghi, M.R.; Mahboubi, A.A.; Nosrati, A.; Dexter, A.R. 2010. Soil water availability for plants as quantified by conventional available water, least limiting water range and integral water capacity. Plant and Soil 335: 229-244.

Bengough, A.G.; Bransby, M.F.; Hans, J.; McKenna, S.J.; Roberts, T.; Valentine, T.A. 2006. Root responses to soil physical conditions: growth dynamics from field to cell. Journal of Experimental Botany 57: 437-447.
Bengough, A.G.; Mullins, C.E. 1990. Mechanical impedance to root growth: a review of experimental techniques and root growth responses. Journal of Soil Science 41: 341-358.

Benjamin, J.G.; Nielsen, D.C.; Vigil, M.F. 2003. Quantifying effects of soil conditions on plant growth and crop production. Geoderma 116: 137-148.

Beutler, A.N.; Centurion, J.F.; Centurion, M.A.P.C.; Freddi, O.S.; Sousa Neto, E.L.; Leonel, C.L.; Silva, A.P. 2007. Traffic soil compaction of an Oxisol related to soybean development and yield. Scientia Agricola 64: 608-615.

Blake, G.R.; Hartge, K.H. 1986. Bulk density. p. 363-375. In: Klute, A., ed. Methods of soil analysis. Part I. Physical and mineralogical methods. 2ed. American Society of Agronomy, Madison, WI, USA.

Busscher, W.J. 1990. Adjustment of flat-tipped penetrometer resistance data to a common water content. Transactions of the ASAE 33: 519-524.

Carr, M.K.V. 2011. The water relations and irrigation requirements of oil palm (Elaeis guineensis): a review. Experimental Agriculture 47: 629-652.

Cassel, D.K.; Nielsen, D.R. 1986. Field capacity and available water. p. 901-926. In: Klute, A., ed. Methods of soil analysis. Part I. Physical and mineralogical methods. 2ed. American Society of Agronomy, Madison, WI, USA.

Cecagno, D.; Andrade, S.E.V.G.; Anghinoni, I.; Kunrath, T.R.; Martins, A.P.; Reichert, J.M.; Gubiani, P.I.; Balerini, F.; Fink, J.R.; Carvalho, P.C.F. 2016. Least limiting water range and soybean yield in a long-term, no-till, integrated crop-livestock system under different grazing intensities. Soil and Tillage Research 156: 54-62.

Ehlers, W.; Köpke, U.; Hesse, F.; Böhm, W. 1983. Penetration resistance and root growth of oats in tilled and untilled loess soil. Soil and Tillage Research 3: 261-275.

Fidalski, J.; Tormena, C.A.; Silva, A.P. 2010a. Least limiting water range and physical quality of soil under groundcover management systems in citrus. Scientia Agricola 67: 448-453.

Fidalski, J.; Auler, P.A.M.; Beraldo, G.; Marur, C.J.; Faria, R.T.; Barbosa, G.M.C. 2010b. Availability of soil water under tillage systems, mulch management and citrus rootstocks. Revista Brasileira de Ciência do Solo 34: 917-924.

Gardner, W.H. 1986. Water content. p. 493-541. In: Klute, A., ed. Methods of soil analysis. Part I. Physical and mineralogical methods. 2ed. American Society of Agronomy, Madison, WI, USA.

Gee, G.W.; Bauder, J.W. 1986. Particle size analysis. p. 383-411. In: Klute, A., ed. Methods of soil analysis. Part I. Physical and mineralogical methods. 2ed. American Society of Agronomy, Madison, WI, USA.

Grable, A.R.; Siemer, E.G. 1968. Effects of bulk density, aggregate size, and soil water suction on oxygen diffusion, redox potential and elongation of corn roots. Soil Science Society of America Journal 32: 180-186.

Klute, A. 1986. Water retention: Laboratory methods. p. 635-660. In: Klute, A., ed. Methods of soil analysis. Part I. Physical and mineralogical methods. 2ed. American Society of Agronomy, Madison, WI, USA.

Lal, R.; Shukla, M.K. 2005. Principles of Soil Physics. 6ed. Marcel Dekker, New York, NY, USA. 
Leão, T.P.; Silva, A.P.; Macedo, M.C.M.; Imhoff, S.; Euclides, V.P.B. 2006. Least limiting water range: a potential indicator of changes in near-surface soil physical quality after the conversion of Brazilian Savanna into pasture. Soil and Tillage Research 88: 279-285.

Leão, T.P.; Silva, A.P.; Perfect, E.; Tormena, C.A. 2005. An algorithm for calculating the least limiting water range of soils. Agronomy Journal 97: 1210-1215.

Letey, J. 1985. Relationship between soil physical properties and crop production. Advances in Soil Sciences 1: 277-294.

Olibone, D.; Encide-Olibone, A.P.; Rosolem, C.A. 2010. Least limiting water range and crop yields as affected by crop rotations and tillage. Soil Use and Management 26: 485-493.

Oliveira, P.D.; Sato, M.K.; Lima, H.V.; Rodrigues, S. 2016. Critical limits of the degree of compactness and soil penetration resistance for the soybean crop in $\mathrm{N}$ Brazil. Journal of Plant Nutrition and Soil Science 179: 78-87.

Peralta, F.; Vásquez, O.; Rachardson, D.L.; Alvarado, A.; Bornemisza, E. 1985. Effect of some soil physical characteristics on yield, growth and nutrition of the oil palm in Costa Rica. Oléagineaux 40: 423-430.

Ramalho-Filho, A.; Motta, P.E.F.; Freitas, P.L.; Teixeira, W.G. 2010. Agroecological Zoning, Production and Management for the Culture of Oil Palm in the Amazon = Zoneamento Agroecológico, Produção e Manejo para a Cultura da Palma de Óleo na Amazônia. Embrapa Solos, Rio de Janeiro, RJ, Brazil (in Portuguese).

Safadoust, A.; Feizee, P.; Mahboubi, A.A.; Gharabaghi, B.; Mosaddeghi, M.R.; Ahrens, B. 2014. Least limiting water range as affected by soil texture and cropping system. Agricultural Water Management 136: 34-41.

Sene, M.; Vepraskas, M.J.; Naderman, G.C.; Denton, H.P. 1985. Relationships of soil texture and structure to corn yield response to subsoiling. Soil Science Society of America Journal 49: 422-427.
Silva, A.P.; Kay, B.D. 1997. Effect of water content variation on the least limiting water range. Soil Science Society of America Journal 61: 884-888.

Silva, A.P.; Kay, B.D.; Perfect, E. 1994. Characterization of the least limiting water range of soils. Soil Science Society of America Journal 58: 1775-1781.

Soil Survey Staff. 2010. Keys to Soil Taxonomy. 10ed. USDANatural Resources Conservation Service, Washington, DC, USA.

Sparks, D.L. 1996. Methods of soil analysis: chemical methods. Part 3. American Society of Agronomy, Madison, WI, USA.

Tormena, C.A.; Silva, A.P.; Libardi, P.L. 1999. Soil physical quality of a Brazilian Oxisol under two tillage systems using the least limiting water range approach. Soil and Tillage Research 52: 223-232.

Williams, J.; Ross, P.; Bristow, K. 1993. Prediction of the Campbell water retention function from texture, structure and organic matter. p. 427-441. In: van Genuchten, M.T.; Leij, F.J.; Lund, L.J., eds. Indirect methods for estimating the hydraulic properties of unsatured soils. U.S. Salinity Lab, Riverside, NY, USA.

Wilson, M.G.; Sasal, M.C.; Caviglia, O.P. 2013. Critical bulk density for a Mollisol and a Vertisol using least limiting water range: effect on early wheat growth. Geoderma 192: 354-361.

Zuraidah, Y.; Ahmad, T.M.; Mohd, H.H.; Abd, R.S. 2012. Oil palm adaptation to compacted alluvial soil (Typic Endoaquepts) in Malaysia. Journal of Oil Palm Research 24: 1533-1541.

Zwieniecki, M.A.; Thompson, M.V.; Holbrook, N.M. 2002. Understanding the hydraulics of porous pipes: tradeoffs between water uptake and root length utilization. Journal of Plant Growth Regulation 21: 315-323. 